\title{
TITLE:
}

\section{DISTRIBUTION AND GROWTH OF THE GASTROPOD STROMBUS LUHUANUS AT SHIRAHAMA, JAPAN}

\section{AUTHOR(S):}

Wada, Keiji; Fukao, Ryuzo; Kuwamura, Tetsuo; Nishida, Mutsumi; Yanagisawa, Yasunobu

\section{CITATION:}

Wada, Keiji ...[et al]. DISTRIBUTION AND GROWTH OF THE GASTROPOD STROMBUS LUHUANUS AT SHIRAHAMA, JAPAN. PUBLICATIONS OF THE SETO MARINE BIOLOGICAL LABORATORY 1983, 28(5-6): 417-432

\section{ISSUE DATE:}

1983-12-26

URL:

http://hdl.handle.net/2433/176066

RIGHT: 


\title{
DISTRIBUTION AND GROWTH OF THE GASTROPOD STROMBUS LUHUANUS AT SHIRAHAMA, JAPAN ${ }^{1}$ )
}

\author{
KeIjI WADA \\ Seto Marine Biological Lahoratory, Kyoto University \\ RYuzo FUKAO \\ Institute of Environmental Toxicology, 4321 Uchimoriya, Mitsukaido, 302-02 Japan \\ Tetsuo KUWAMURA \\ Faculty of Liberal Arts, Chukyo University, Yagoto Honmachi, Nagoya, 466 Japan \\ Mutsumi NISHIDA \\ Department of Marine Sciences, University of the Ryukyus, Nishihara, Okinawa, 903-01 Japan \\ and \\ YASUNOBU YANAGISAWA \\ Department of Biology, Ehime University, Bunkyo, Matsuyama, 790 Japan
}

With Text-figures 1-11, Tables 1-2 and Appendixes 1-3

\begin{abstract}
Spatial distribution and growth of the gastropod Strombus luhuanus were investigated in the shallow waters of Shirahama, Japan. Newly settled juveniles smaller than $25 \mathrm{~mm}$ in shell length were found mainly on the rock flat shallower than ca. $5 \mathrm{~m}$, where few adults were found. From $0^{+}$to $1^{+}$year, they migrated downward to the fringe of rock and its adjacent areas, as they grew up to $40 \mathrm{~mm}$ in shell length, and then merged to the adult populations. At the age of $2^{+}$years, they attained to 40$60 \mathrm{~mm}$ in shell length and some of them migrated offshore afterwards. Maturity and thickening of shell-lip usually occurred at the age of $2^{+}$years or older. Adults showed seasonal changes in their distribution pattern. In winter they aggregated on the sand-pebble and near the fringe of rock, while from late spring to autumn they extended their distribution over sand and mud areas, offshore and inshore. Only in summer, many adults appeared on the sand-pebble area near the shoreline, being concurrent with coupling and spawning. S. luhuanus, thus, use the various substrata as their habitat, according to the life stages.
\end{abstract}

\section{Introduction}

In general, spatial distributions of sublittoral gastropods have not been studied so in detail as in intertidal ones. Strombus luhuanus (Linnaeus, 1758), a mesogastropod of the family Strombidae, is reported to occur in shallow sublittoral zone and to have wide geographical distributions in the tropical and subtropical regions of the

1) Contributions from the Seto Marine Biological Laboratory, No. 694.

Publ. Seto Mar. Biol. Lab., XXVIII (5/6), 417-432, $1983 . \quad$ (Article 7) 
western Pacific Ocean (Abott, 1960). Among the strombid species, the queen conch Strombus gigas in the Atlantic Ocean has been studied most intensively due to its economical importance (Randall, 1964; D’Asaro, 1965; Berg, 1976; Brownell, 1977; Hesse, 1979). But $S$. luhuanus has received comparatively little attention. Frank (1969) briefly noted the growth rate of $S$. luhuanus on the coral reef at Heron Island and Berg (1974) described its behaviors of locomotion, feeding, righting and escape, but there have been no work dealing with its spatial distribution. This paper mainly deals with the growth and the spatial distribution of this conch at Shirahama, Japan, and elucidates the dynamics of their distribution in relation to growth and season.

\section{Study Area and Methods}

Field surveys were carried out in the waters around the Seto Marine Biological Laboratory located on the south coast of Tanabe Bay $\left(33^{\circ} 42^{\prime} \mathrm{N}\right.$ and $135^{\circ} 20^{\prime} \mathrm{E}$ ) (Fig. 1). In this area, many irregular rocky reefs are interspaced with bottoms of various substrata, i.e. boulder, pebble, sand and mud. Fig. 2 shows that temperatures of

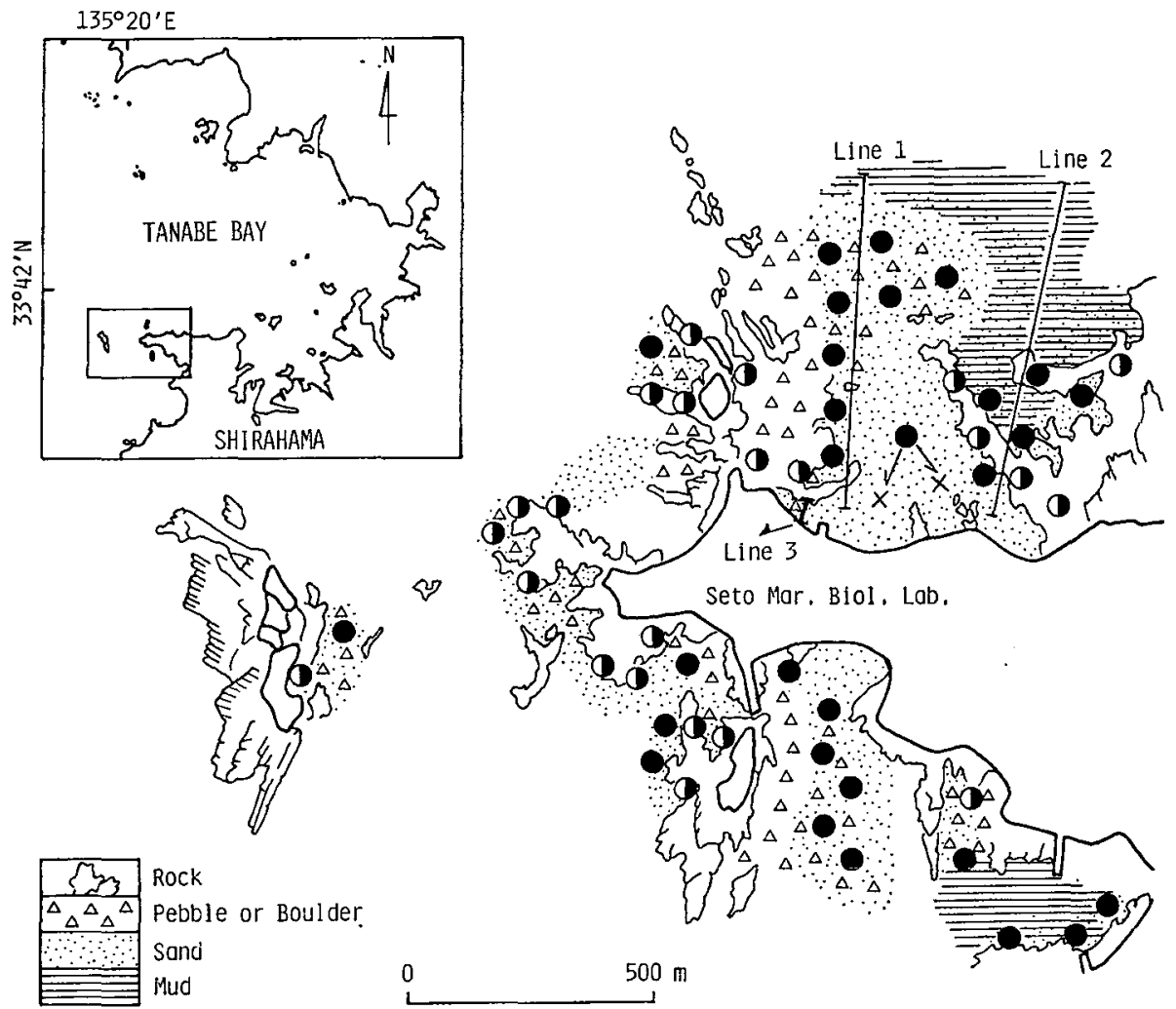

Fig. 1. Map of the study area showing the substrata and! ocations of three census lines (Lines 1, 2 and 3). Bold line indicates the approximate highest shoreline at spring tide. Distribution of $S$. luhuanus in the period of December 1975 to March 1976 is also shown. Solid circle: conchs larger than ca. $40 \mathrm{~mm}$ in shell length. Half-solid circle: conchs smaller than ca. 40 $\mathrm{mm}$. X: area where Zostera japonica grew. 


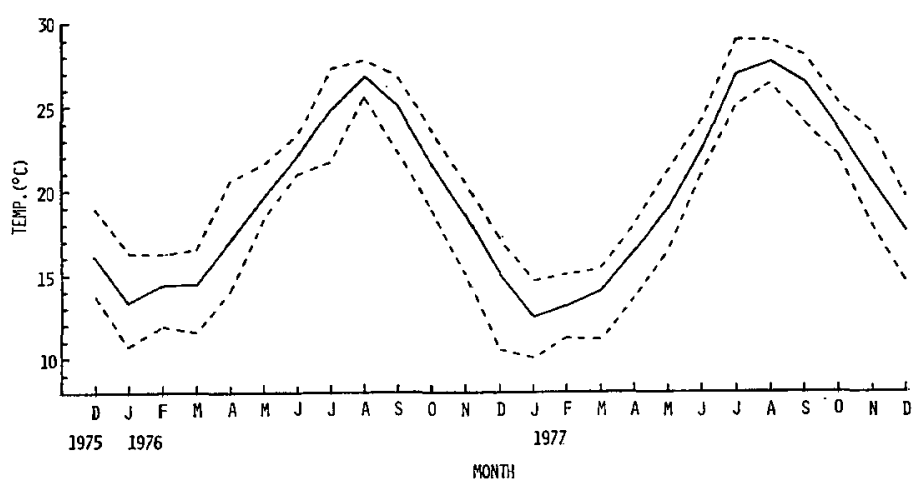

Fig. 2. Monthly average (solid line), maximum (upper broken line) and minimum (lower broken line) water temperatures measured at 9:00 at the north shore of the laboratory during the survey period.

the surface water are highest in August (ca. $27^{\circ} \mathrm{C}$ ) and lowest in January (ca. $13^{\circ} \mathrm{C}$ ).

Three census lines, Line 1 (700 $\mathrm{m}$ long), Line $2(700 \mathrm{~m})$ and Line $3(50 \mathrm{~m})$, were set in the north of the laboratory, almost perpendicularly to the shoreline (Fig. 1). Line 1 traversed sand and sand-pebble bottoms and two small rocks. Line 2 traversed two large rocks and sand and mud bottoms. . Details of depth, substratum and epibenthic organisms except $S$. luhuanus along Lines $1 \& 2$ are shown in Appendixes 1-3. Line 3 was set at the shallow sand-pebble bottom. As a rule, line censuses were made montly from April 1976 to June 1977. In each census, the numbers of larger conchs ( $>$ ca. $40 \mathrm{~mm}$ in shell length) and smaller ones ( < ca. 40 $\mathrm{mm}$ ) were counted in the area of $1 \mathrm{~m}$ wide strip along the lines and the record was taken from each $10 \mathrm{~m}$ length of the line separately. At the same time, about 80 conchs were collected at each of six stations, $100 \mathrm{~m}, 300 \mathrm{~m}$ and $500 \mathrm{~m}$ offshore points of Line 1 (L-1-100, L-1-300 and L-1-500), $100 \mathrm{~m}$ and $300 \mathrm{~m}$ offshore points of Line 2 (L-2-100 and L-2-300), and around Line $3(\mathrm{~L}-3)$. All these samples were measured for shell length, and the thickness of their shell-lips were briefly examined.

A part of conchs in the study area were tagged with DYMO plastic tapes; a numbered tape was tied to them with monofilament nylon line through a holl bored in the outer lip of the shell, with the knot being fixed with the adhesive agent "Aron Alpha". The numbers of tagged conchs were as follows: On the west of L-1-100, 300, 297 and 236 conchs were collected and tagged in August, October 1976 and March 1977, respectively, and around L-1-300, 241 conchs in March 1977. Most of the conchs tagged in October 1976 were $30-40 \mathrm{~mm}$ in shell length, whereas the majority of the conchs tagged in other periods were larger $(40-60 \mathrm{~mm})$. Tagged conchs were recaptured periodically until December 1977, and measured for their shell lengths.

In addition to the above routine works, we occasionally dived around the coast of the laboratory in order to know the general distribution pattern of $S$. luhuanus; particularly the shallow areas where the smaller conchs occurred abundantly were scanned intensively with regard to their densities and size structures. 


\section{Results}

Growth. S. luhuanus spawned egg masses from late May to late August and planktonic veligers hatched out from the eggs (Kuwamura et al., 1983). The smallest conch collected was $6.8 \mathrm{~mm}$ in shell length. It was captured on 7 September 1977, and might be regarded as a newly settled juvenile which had been spawned in the same year. Fig. 3 shows size-frequency distributions of conchs collected from various substrata and depths from December 1975 to March 1977. The conchs around 20 $\mathrm{mm}$ in December 1975 can be regarded as $0^{+}$year group, and they continued to grow and reached $30-40 \mathrm{~mm}$ in December 1976 at the age of $1^{+}$year. Most of the conchs tagged in October 1976, thus, can be regarded as $1^{+}$year on tagging from their sizes $(30-40 \mathrm{~mm})$. They grew to $35-45 \mathrm{~mm}$ in September 1977 when $2^{+}$year (Fig. 4). The growth rate varied with season: their shell lengths scarcely increased

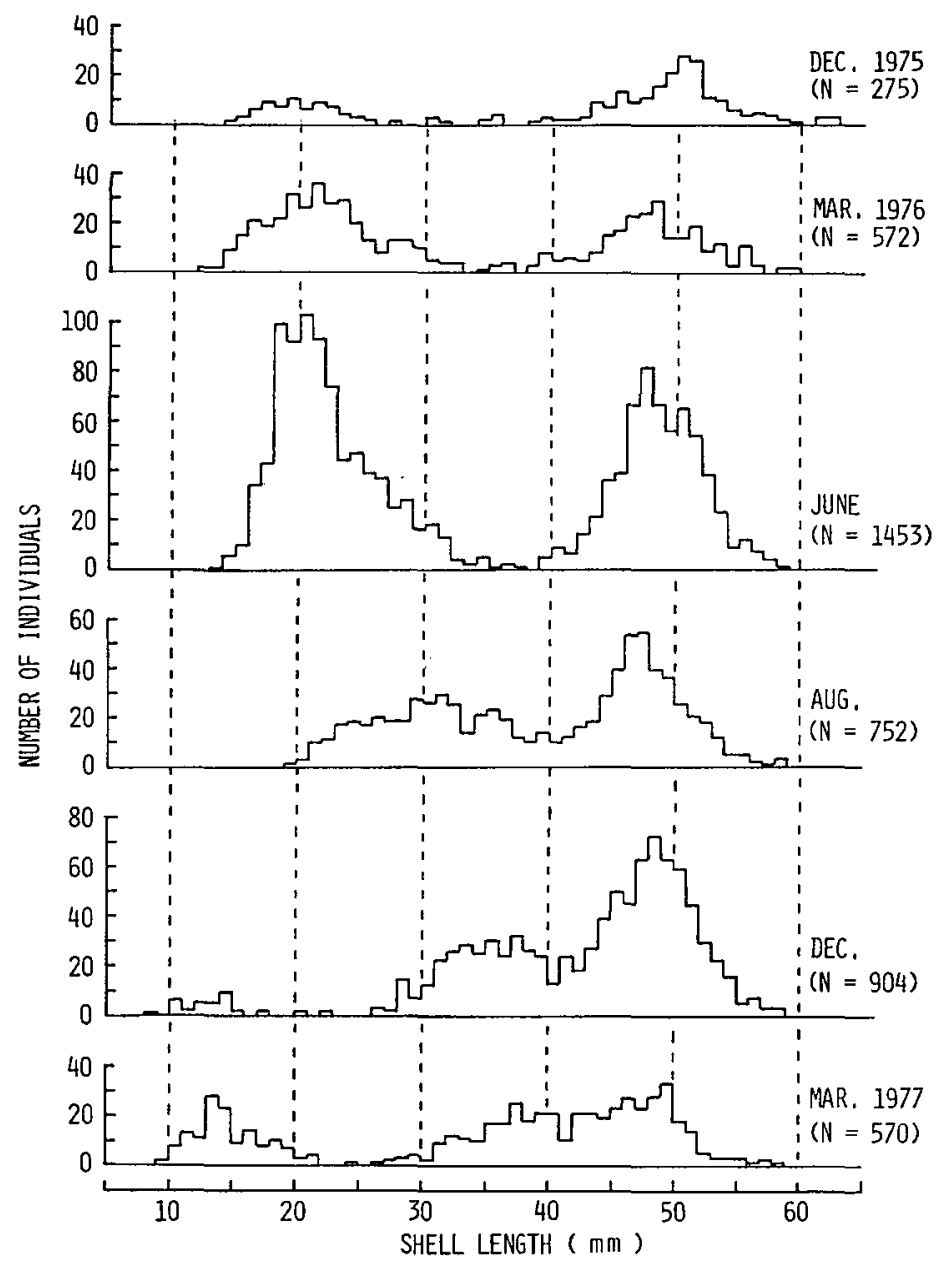

Fig. 3. Size-frequency distributions of $S$. luhuanus from various substrata and depths combined around the coast of the laboratory from December 1975 to March 1977. 


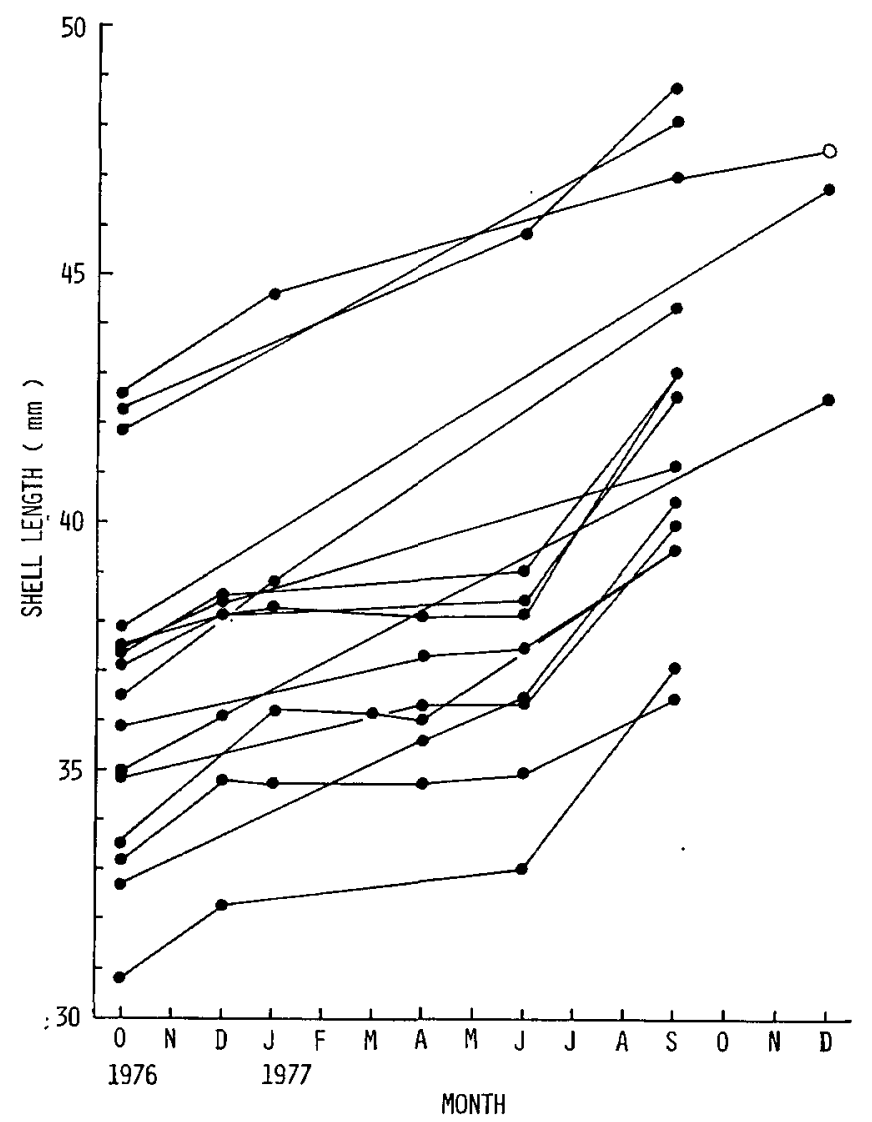

Fig. 4. Individual growth of $S$. luhuanus tagged in October 1976, until September or December 1977. The solid and open circles indicate that the shell-lips were thin and thickened, respectively.

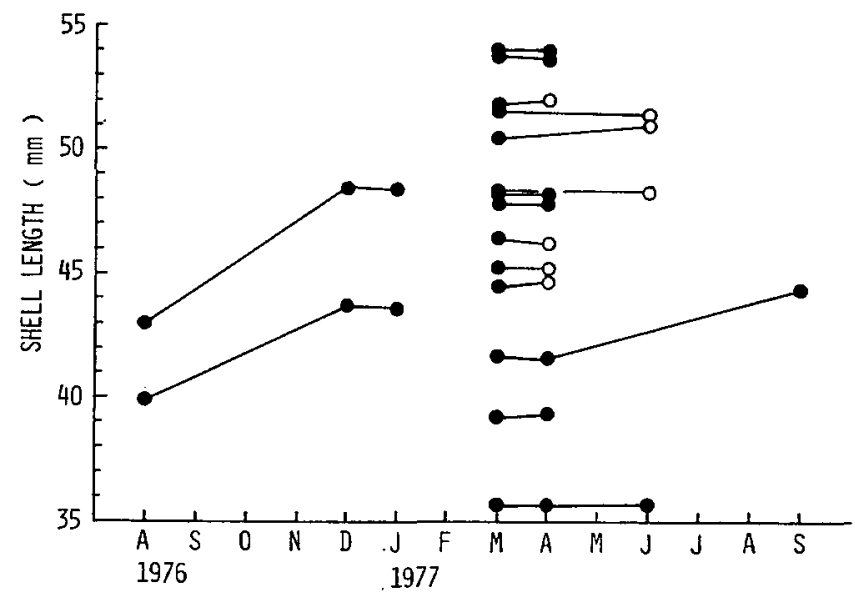

MONTH

Fig. 5. Individual growth of $S$. luhuanus tagged in August and October 1976, and March 1977. Only conchs, the shell-lips of which were thin on tagging, are shown. The solid and open circles indicate that the lips were thin and thickened, respectively. 
Table 1. Seasonal variation in the growth rate of shell length in S. luhuanus tagged in October 1976, until September 1977. S.E.: standard error.

\begin{tabular}{|c|c|c|c|c|c|c|c|}
\hline \multirow{2}{*}{ Period } & \multirow{2}{*}{$\mathbf{N}$} & \multirow{2}{*}{$\begin{array}{c}\text { Interval } \\
\text { (days) }\end{array}$} & \multicolumn{2}{|c|}{$\begin{array}{c}\text { Initial shell } \\
\text { length }(\mathrm{mm})\end{array}$} & \multicolumn{2}{|c|}{ Increment (mm) } & \multirow{2}{*}{$\begin{array}{c}\text { Mean increment } \\
\text { per } 30 \text { days } \\
(\mathrm{mm})\end{array}$} \\
\hline & & & Mean & S.E. & Mean & S.E. & \\
\hline Oct.-Dec., 1976 & 123 & 54 & 36.14 & 0.28 & 1.56 & 0.06 & 0.88 \\
\hline Dec. 1976-Apr. 1977 & 47 & 144 & 37.81 & 0.42 & 0.05 & 0.05 & 0.01 \\
\hline Apr.-June, 1977 & 64 & 41 & 37.70 & 0.26 & 0.59 & 0.05 & 0.43 \\
\hline June-Sept., 1977 & 9 & 91 & 37.80 & 1.18 & 3.44 & 0.37 & 1.15 \\
\hline
\end{tabular}

Table 2. Growth rate of shell length in S. luhuanus with thickened lips, tagged in August and October 1976, and March 1977.

\begin{tabular}{lrrrr}
\hline \multicolumn{1}{c}{ Period } & $\mathrm{N}$ & & \multicolumn{2}{c}{ Increment (mm) } \\
\cline { 3 - 5 } & & Max. & Min. & Mean \\
\hline Jan.-Apr., 1977 & 4 & 0.1 & -0.2 & -0.03 \\
Mar.-Apr., 1977 & 77 & 0.6 & -0.8 & -0.14 \\
Mar.-June, 1977 & 46 & 0.4 & -0.6 & -0.17 \\
Mar.-Sept., 1977 & 16 & 0.4 & -0.6 & -0.23 \\
Mar.-Dec., 1977 & 12 & 1.1 & -0.9 & -0.18 \\
Apr.-June, 1977 & 11 & 0.1 & -0.3 & -0.06 \\
Apr.-Sept., 1977 & 3 & 0.2 & -0.3 & -0.10 \\
Apr.-Dec., 1977 & 3 & 0.8 & -0.3 & 0.13 \\
June-Sept., 1977 & 5 & 0.5 & -0.4 & -0.10 \\
\hline
\end{tabular}

in winter, whereas they increased most markedly in summer (Table 1). Among conchs larger than $40 \mathrm{~mm}$, those with thin shell-lips more or less increased the shell length (Figs. $4 \& 5$ ), but those with thickened lips scarcely did in any season (Table 2). The smallest conch with the thickened lip was $39.0 \mathrm{~mm}$ in shell length, and the largest conch with the thin lip was $58.1 \mathrm{~mm}$. The shell-lip is, thus, supposed to become thickened when $2^{+}$year at the earliest, with the shell length being variable.

Since the smallest conchs observed copulating were $40.6 \mathrm{~mm}$ in shell length for the male and $33.6 \mathrm{~mm}$ for the female, some conchs may commence to breed at the age of $\mathrm{1}^{+}$year. However, most of the coupling and/or spawning conchs were observed to have thickened lips, and therefore maturity is supposed to be usually reached at the age of $2^{+}$or older. Longevity is estimated at more than three years, because two tagged conchs which had thickened lips in March 1977, probably at the age of $2^{+}$or older, were found alive in July 1978.

Mortality. In June and August 1976, we encountered many larger conchs in a moribund condition on the intertidal pebbly beach near Line 3. During the period, the sea around the laboratory continued to be rough, which might have caused the conchs to be stranded. When the water temperature was very low in winter, we sometimes found many freshly dead conchs whose shells were still fresh, not crushed and not drilled. These conchs might have died of low water temperature. 
As for predators, a swimming crab, Charybdis natator and an octopus, Octopus sp. can be pointed out; actual attacking of the crab and of the octopus on the conch was witnessed in a rearing tank and in the field, respectively.

Distribution and size structure. S. luhuanus was distributed widely around the laboratory (Fig. 1). They were found mainly on the sand-pebble bottom, and on and near the rocks. The distribution of the smaller conchs tended to be biased to shallower areas, as compared with that of larger conchs.

Conchs smaller than $25 \mathrm{~mm}$ were found mainly on the rock flats at the depth of 1 to ca. $5 \mathrm{~m}$, where only few larger conchs $(>40 \mathrm{~mm}$ ) occurred. These rock flats were usually covered with coralline and other algae such as Padina arborescens, Colpomenia sinuosa, Sargassum spp., Actinotrichia fragilis, Galaxaura fastigata and Gelidium amansii. The juveniles were embedded in a cluster of these algae and in small depressions on the rock. The maximum density was $70 / 1 \mathrm{~m}^{2}$. Conchs of $25-40 \mathrm{~mm}$ in shell length were found mainly on the rock flat at the depth of 2 to ca. $10 \mathrm{~m}$ and the adjacent sand and sand-pebble bottom. Thus, the sizes of conchs increased as the habitat shifts from the shallow rock flat to the sand-pebble bottom (Fig. 6). Such difference of size structure indicates that the conchs migrate downwards from rock to sand-pebble bottom as they grow.

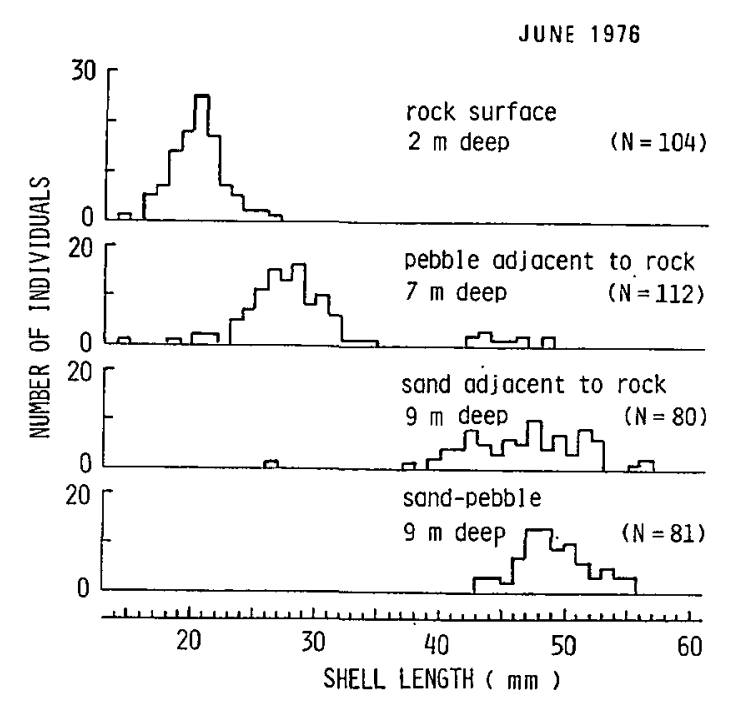

Fig. 6. Size-frequency distributions of $S$. luhuanus collected from different substrata and depths in June 1976.

Size structures of conchs collected at six stations on the three lines are shown in Fig. 7. The samples from the inshore stations of L-1-100 (sand bottom adjacent to rock), L-2-100 (rock flat) and L-3 (sand-pebble bottom) consisted of not only the larger conchs $(>40 \mathrm{~mm})$ but also smaller ones $(30-40 \mathrm{~mm})$. Almost all the conchs from the offshore stations of L-1-300 (sand bottom), L-1-500 (sand-pebble bottom) and L-2-300 (rock flat) were of large-sized $(>40 \mathrm{~mm}$ ) all the year round. The 

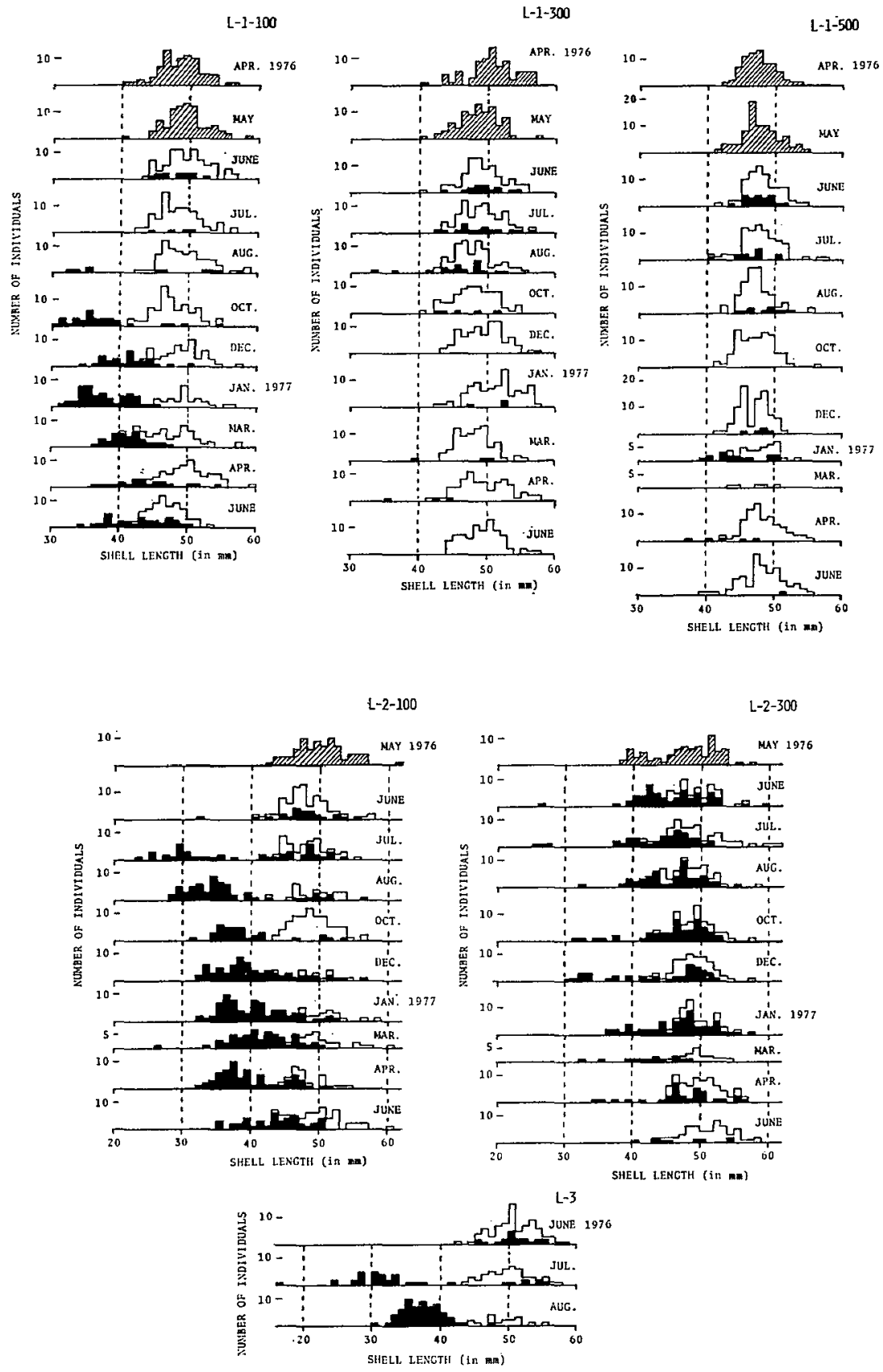

Fig. 7. Size-frequency distributions of $S$. luhuanus collected at L-1-100, L-1-300, L-1-500, L-2-100, L-2-300 and L-3 from April 1976 to June 1977. Solid and open histograms indicate the conchs with thin shell-lips and those with thickened shell-lips, respectively. For the samples collected in April and May 1976 (shaded histograms), the thickness of the shell-lip was not recorded. 


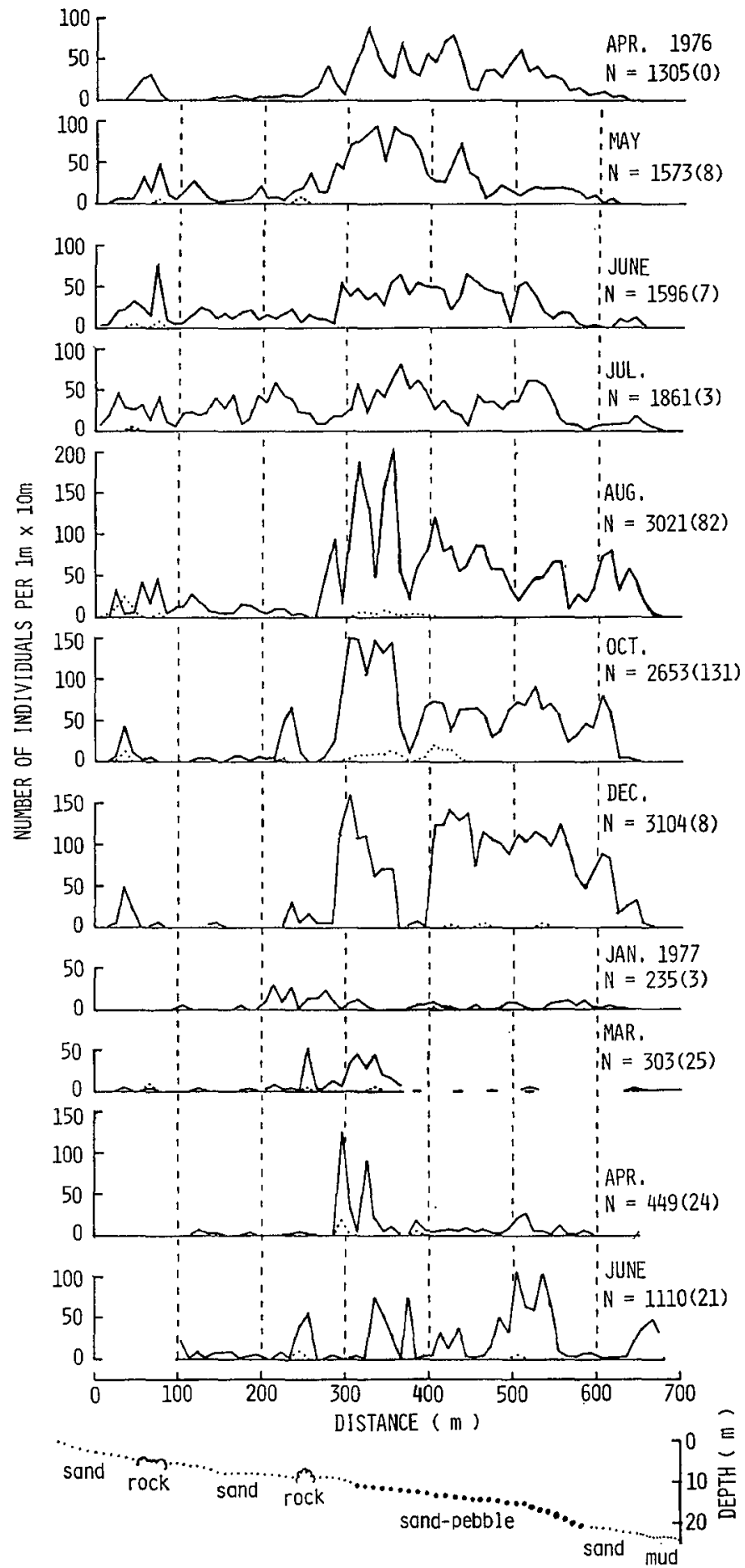

Fig. 8. Distribution of S. luhuanus along Line 1, with its bottom profile. The number of conchs per 1 $\mathrm{m} \times 10 \mathrm{~m}$ is shown, separately for the conchs larger than ca. $40 \mathrm{~mm}$ (solid line) and those smaller than ca. $40 \mathrm{~mm}$ (dotted line) in shell length. Total number of conchs counted on the line is shown for each month, with that of smaller conchs in parenthesis. From March to June 1977, some areas, which are shown by broken sections of the abscissas, were not surveyed. 
larger conchs from L-1-300 and L-1-500 mostly had thickened shell-lips, whereas at L-2-300 those with thin shell-lips accounted for higher proportion than those with thickened shell-lips. These facts indicate that some of larger conchs with thickened shell-lips migrate from inshore area or from offshore rock flat to the offshore sand and sand-pebble areas.

The conchs along Line 1 were mostly of large-sized $(40-60 \mathrm{~mm})$ (Fig. 8). They

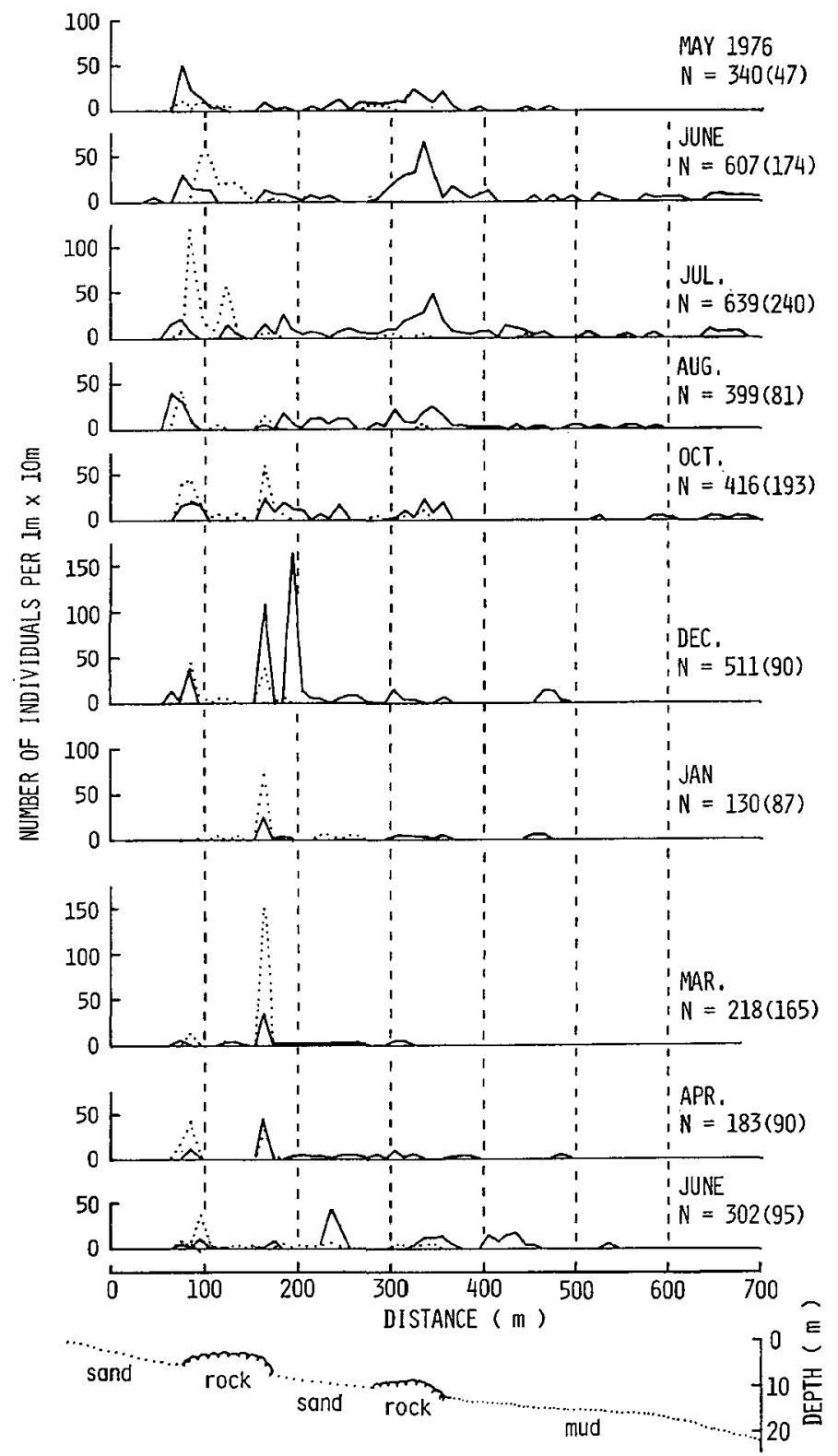

Fig. 9. Distribution of S. luhuanus along Line 2, with its bottom profile. Details as for Fig. 8. 
were abundant on or near the rock flat of 40 to $80 \mathrm{~m}$ point of the line and on the sand-pebble bottom of 300 to $600 \mathrm{~m}$ point. In the latter area, their densities were high from August to December (the maximum density: $208 / 10 \mathrm{~m}^{2}$ ), and relatively low from May to July (the maximum density: $98 / 10 \mathrm{~m}^{2}$ ). In the sand or mud areas such as 0 to $40 \mathrm{~m}, 80$ to $240 \mathrm{~m}$ and 600 to $700 \mathrm{~m}$ points, on the other hand, their densities were relatively higher in the period of May or June to October or December. This fact means that larger conchs extend their distribution to sand or mud area, whether inshore or offshore, in this period. In the cold season from January to April, patches of densely aggregated conchs were distributed sporadically on the sand-pebble bottom and near the rock along the line. In the cold season, the total number of conchs found along the line much decreased. Many conchs were observed to bury their bodies partly or wholly in sand during this period, hence this decrease may be in part due to the oversight of the buried conchs.

Along Line 2, conchs were abundantly found on two rocks and the adjacent sand bottoms (Fig. 9). The smaller conchs $(<40 \mathrm{~mm}$ ) were more abundant on the rock of $70 \mathrm{~m}$ to $170 \mathrm{~m}$ point of the line (the maximum density: $149 / 10 \mathrm{~m}^{2}$ ) than of $280 \mathrm{~m}$ to $350 \mathrm{~m}$ (the maximum density: $10 / 10 \mathrm{~m}^{2}$ ). On the former rock flat, the distributional peak of the smaller conchs shifted from the middle to the fringe of the rock from June to August 1976. This may reflect the downward migration of the smaller conchs. As observed on Line 1, larger conchs on the sand or mud bottom areas such as 0 to $70 \mathrm{~m}, 170$ to $280 \mathrm{~m}$ and 350 to $700 \mathrm{~m}$ points were fewer from January to April than in other periods. In December, a high density of larger conchs (164 individuals) was recorded at the sandy area of 190-200 m point, where a large

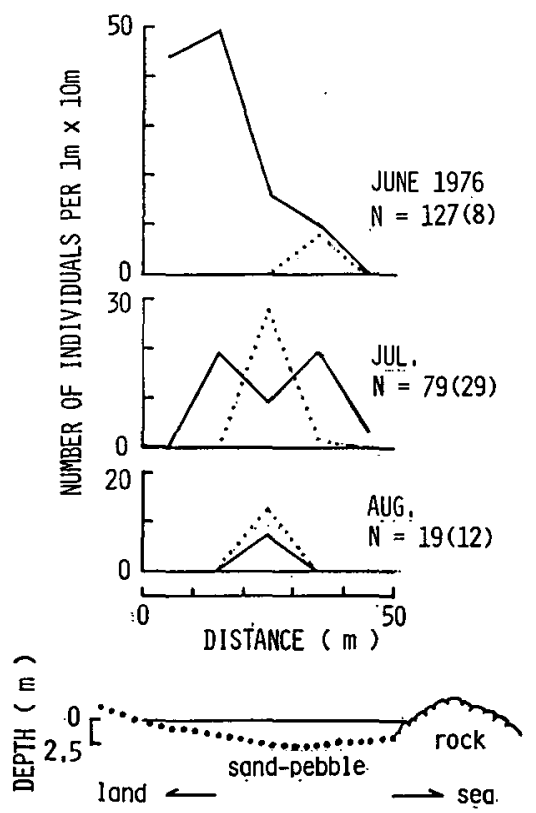

Fig. 10. Distribution of $S$. luhuanus along Line 3, with its bottom profile. Details as for Fig. 8. 
aggregation of conchs covering the area of about $18 \mathrm{~m}^{2}$ were formed.

At Line 3, conchs appeared only in the period of June to August in 1976 (Fig. 10). In June 1976, the conchs, most of which were of large-sized, aggregated on the pebbly slope near the water edge. Most conchs there were coupling and spawning. In July and August 1976, the number of larger conchs decreased, while smaller ones were more abundant than in June. In the summer of 1977, no conchs appeared around Line 3, but many larger conchs were observed to spawn in the shallow area near the pier situated ca. $50 \mathrm{~m}$ eastward from Line 3 , where conchs were absent in other months.

\section{Discussion}

S. luhuanus, at Shirahama, were commonly found at various substrata. However, the habitats of juveniles and adults were segregated; in other words, the habitat shift with growth was observed, as shown in Fig. 11. Newly settled juveniles inhabited small depressions and interstices of seaweeds on the shallow rock flat. From $0^{+}$to $\mathrm{1}^{+}$ year, they migrated downward to the fringe of rock and the adjacent sand or sandpebble areas, recruiting into adult populations. At the age of $2^{+}$years or older, they became adults, with their shell-lips thickened, and some of them migrated offshore. The habitat difference between juveniles and adults has not so far been demonstrated in $S$. luhuanus, though it was noted that small individuals were never seen in the field (Frank, 1969). In other species of Strombus, it was reported for $S$. pugilus that juveniles were segregated from adult populations (Percharde, 1968). Contrary, juveniles of $S$. pugilus, $S$. gigas and $S$. costatus were reported to be found together with adults (Brownell, 1977). Habitat shift with growth has been known also in other intertidal and subtidal gastropods, e.g., Purpura lapillus (Moore, 1938), Melarapha praetermissa and $M$. unifasciata (Bennett \& Pope, 1960), Decathais orbita (Phillips, 1969), Tegula funebralis (Paine, 1969), and Omphalius pfeifferi (Horikawa \& Yamakawa, 1982). But in these works the reason for the situation has not been clarified decisively, though Moore pointed out the diet difference between juveniles and adults as the reason by providing some evidence. As with $S$. luhuanus, it is unknown whether the food preference is different between juveniles and adults. From the view point of refuge, the small depressions or interstices of seaweeds on

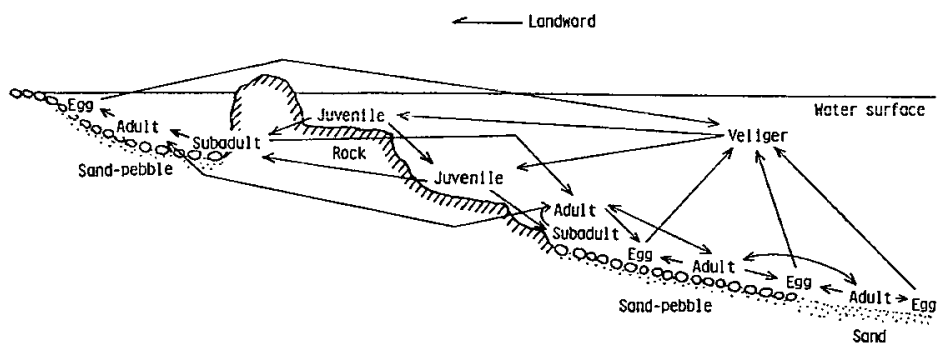

Fig. 11. Diagrammatic summary of habitat shift of $S$. luhuanus with successive growth stages. Juvenile, subadult and adult correspond to the conchs of the ages of $0^{+}, 1^{+}$and $2^{+}$years or older, respectively. 
the shallow rock flat may be regarded more suitable for juveniles than adult habitat such as sand or sand-pebble bottom. Habitat difference between different growth stages, though the reason is not clear in detail, may result in avoiding the intraspecific competition for spatial occupation, and in this sense it might be understood as the successful pattern of habitat use, characteristic of motile animals.

The seasonal change of distribution was also observed in adult $S$. luhuanus at Shirahama. Though adults mainly occurred near the fringe of rock and on the sand-pebble area, they extended their distribution over the sand and mud areas, both offshore and inshore, from late spring to autumn or to early winter. In $S$. gigas, the migration from seagrass beds into sand flats is considered to be associated with egg laying and with need to burying themselves partially for shell deposition (Randall, 1964). In case of S. luhuanus, however, the former explanation is not applicable, because its main spawning sites were not bare sand but pebble or sand-pebble area (Kuwamura et al., 1983); the latter explanation seems unlikely, because most of $S$. luhuanus were active and not buried in sand in this period. In winter, $S$. luhuanus were mostly inactive, whereas in other seasons many conchs were observed to feed actively on sand and mud bottoms as well as on other substrata. The appearance in sand or mud area, thus, may be understood as the expansion of feeding ground. To compare the activity between the conchs in the sand or mud area and those in other habitats is needed for the future study for this problem.

In the summer months, the appearance of adult conchs on the sand-pebble bottom near the shoreline was also observed, as exemplified around Line 3 . This phenomenon is considered to be more related to breeding, for the appearance period was limited to the breeding season of June to August (Kuwamura et al., 1983) and many conchs coupled and spawned there.

Thus, as summarized in Fig. 11, the habitat of $S$. luhuanus is not limited to a definite kind of substratum, but they fully utilize various kinds of substrata from shoreline to ca. $700 \mathrm{~m}$ offshore and ca. $20 \mathrm{~m}$ depth, according to the growth stages and to the season.

\section{Acknowledgments}

We would like to express our sincere thanks to Prof. E. Harada (Kyoto University), Prof. M. Nishihira and Dr. M. Yamaguchi (University of the Ryukyus) for critical reading of the manuscript. Appreciation is also expressed to the members of the staff of the Seto Marine Biological Laboratory for encouragements and advice given to us during the course of the study, in particular to $\mathrm{Mr}$. T. Yamamoto for identification of algae and Messrs. K. Yoshimura and M. Ishihara for partial assistance of the work. This work was supported in part by a Grant-in-Aid for Special Project Research on Biological Aspects of Optimal Strategy and Social Structure from Japan Ministry of Education, Science and Gulture. 


\section{References}

Abbott, R.T. 1960. The genus Strombus in the Indo-Pacific. Indo Pacific Mollusca, 1: 33-146.

Bennett, I. \& E.C. Pope. 1960. Intertidal zonation of the exposed rocky shores of Tasmania and its relationship with the rest of Australia. Aust. J. mar. Freshwat. Res., 11: 182-221.

Berg, C.J. 1974. A comparative ethological study of strombid gastropods. Behaviour, 51: 274-322. 1976. Growth of the queen conch Strombus g:gas, with a discussion of the practicality of its mariculture. Mar. Biol., 34: 191-200.

Brownell, W.N. 1977. Reproduction, laboratory culture, and growth of Strombus gigas, S. costatus and $S$. pugilus in Los Roques, Venezuela. Bull. Mar. Sci., 27: 668-680.

D'Asaro, C.N. 1965. Organogenesis, development, and metamorphosis in the queen conch, Strombus gigas, with notes on breeding habits. Ibid., 15: 359-416.

Frank, P.W. 1969. Growth rates and longevity of some gastropod molluscs on the coral reef at Heron Island. Oecologia (Ber.), 2: 232-250.

Hesse, K.O. 1979. Movement and migration of the queen conch, Strombus gigas, in the Turks and Caicos Islands. Bull. Mar. Sci., 29: 303-311.

Horikawa, H. \& H. Yamakawa. 1982. Ecological study of Omphalius pfeifferi Philippi (Gastropoda: Prosobranchia). Bull. Nansei Reg. Fish. Res. Lab., No. 14: 71-81. (In Japanese with English summary).

Kuwamura, T., R. Fukao, M. Nishida, K. Wada \& Y. Yanagisawa. 1983. Reproductive biology of the gastropod Strombus luhuanus (Strombidae). Publ. Seto Mar. Biol. Lab., 28: 433-443.

Moore, H.B. 1938. The biology of Purpura lapillus. Part III. Life history and relation to environmental factors. J. mar. biol. Ass. U.K., 23: 67-74.

Paine, R.T. 1969. The Pisaster-Tegula interaction: prey patches, predator food preference and intertidal community structure. Ecology, 50: 950-961.

Percharde, P.L. 1968. Notes on distribution and underwater observations on the molluscan genus Strombus as found in the waters of Trinidad and Tobago. Carib. J. Sci, 8: 47-53.

Phillips, B.F. 1969. The population ecology of the whelk Dicathais aegrota in Western Australia. Aust. J. mar. Freshwat. Res., 20: 225-265.

Randall, H.A. 1964. Contributions to the biology of the queen conch, Strombus gigas. Bull. Mar. Sci., 14: 246-295. 
Appendix 1. Depth, substratum and prominent epibenthic organisms along Line 1 during the survey period. The asterisked species occurred from winter to spring.

\begin{tabular}{|c|c|c|c|c|}
\hline $\begin{array}{l}\text { Distance from } \\
\text { the starting } \\
\text { point } \\
\text { (m) }\end{array}$ & $\begin{array}{l}\text { Depth } \\
\text { (m) }\end{array}$ & Substratum & $\begin{array}{l}\text { Epibenthic animals } \\
\text { except } S . \text { luhuanus }\end{array}$ & Seaweeds \\
\hline $0-40$ & $2.5-3$ & sand & & \\
\hline $40-80$ & $2-4.5$ & rock & $\begin{array}{l}\text { Acropora spp. } \\
\text { Echinometra mathaei } \\
\text { Toxopnetustes pileolus } \\
\text { Holothuria pervicax } \\
\text { * Aplysia juliana }\end{array}$ & *Undaria undarioides \\
\hline $80-240$ & $4.5-8.5$ & sand & $\begin{array}{l}\text { Clypeaster japonicus } \\
\text { Peronella japonica } \\
\text { Astropecten scoparius }\end{array}$ & $\begin{array}{l}\text { Zostera japonica } \\
\text { Halophila ovalis } \\
\text { Colpomenia sinuosa }\end{array}$ \\
\hline $240-260$ & $6-8.5$ & rock & $\begin{array}{l}\text { Diadema setosum } \\
\text { Spondylus barbatus barbatus }\end{array}$ & Colpomenia sinuosa \\
\hline $260-300$ & $8-9$ & sand & & $\begin{array}{l}\text { Zostera japonica } \\
\text { Halophila ovalis } \\
\text { Scinaia japonica }\end{array}$ \\
\hline $300-600$ & $9-20$ & $\begin{array}{l}\text { sand-pebble } \\
\text { (Most of the } \\
\text { pebbles were } \\
20-80 \mathrm{~mm} \text { in } \\
\text { diameter.) }\end{array}$ & $\begin{array}{l}\text { Aglaophenia whiteleggei } \\
\text { Cladiella digitulata } \\
\text { Toxopneustes pileolus } \\
\text { Clypeaster japonicus } \\
\text { Spondylus barbatus barbatus } \\
\text { Hyotissa hyotis imbricata } \\
\text { *Aplysia juliana }\end{array}$ & $\begin{array}{l}\text { * Undaria undarioides } \\
\text { * Scinaia japonica } \\
\text { *Gracilaria textorii } \\
\text { * Lomentaria catenata } \\
\text { * Gracilaria bursa-pastoris } \\
\text { * Halymenia acuminata } \\
\text { Hypnea yamadai } \\
\text { Sargassum piluliferum }\end{array}$ \\
\hline $600-650$ & 20 & $\begin{array}{l}\text { sand (dead } \\
\text { shells in } \\
\text { places) }\end{array}$ & & \\
\hline $650-700$ & $20-22$ & mud & & \\
\hline
\end{tabular}

Appendix 2. Depth, substratum and prominent epibenthic organisms along Line 2 during the survey period. The asterisked species occurred from winter to spring.

\begin{tabular}{|c|c|c|c|c|}
\hline $\begin{array}{l}\text { Distance from } \\
\text { the starting } \\
\text { point } \\
\text { (m) }\end{array}$ & $\begin{array}{l}\text { Depth } \\
(\mathrm{m})\end{array}$ & Substratum & $\begin{array}{l}\text { Epibenthic animals } \\
\text { except } S . \text { luhuanus }\end{array}$ & Seaweeds \\
\hline $0-70$ & $2-5$ & sand & Astropecten latespinosus & \\
\hline $70-170$ & $2.5-6$ & rock & $\begin{array}{l}\text { Acropora spp. } \\
\text { Cladiella digitulata } \\
\text { Echinometra mathaei } \\
\text { Echinostrephus aciculatus } \\
\text { Diadema setosum } \\
\text { * Aplysia juliana }\end{array}$ & $\begin{array}{l}\text { *Ecklonia kurome } \\
\text { Colpomenia sinuosa } \\
\text { calcareous algae }\end{array}$ \\
\hline $170-280$ & $6-10$ & muddy sand & Astropecten scoparius & Halophila ovalis \\
\hline $280-350$ & $9-10$ & rock & $\begin{array}{l}\text { Acropora spp. } \\
\text { Cladiella digitulata } \\
\text { Diadema setosum } \\
\text { Toxopnetstes pileolus } \\
\text { Clypeaster japonicus } \\
\text { Holothuria hilla } \\
\text { Chlamys nobilis }\end{array}$ & $\begin{array}{l}\text { * Undaria undarioides } \\
\text { Colpomenia sinuosa } \\
\text { Dictyopteris undulata } \\
\text { Sargassum piluliferum } \\
\text { Gelidium amansii }\end{array}$ \\
\hline $350-700$ & $11-22$ & $\begin{array}{l}\text { mud or } \\
\text { sandy mud }\end{array}$ & $\begin{array}{l}\text { Virgularia gustaviana } \\
\text { Leioptilus fimbriatus } \\
\text { Dofleinia armata } \\
\text { Styela plicata }\end{array}$ & \\
\hline
\end{tabular}


Appendix 3. Wet weights (in gram) of seaweeds per $1 \mathrm{~m}^{2}$ at $400 \mathrm{~m}$ and $500 \mathrm{~m}$ points of Line 1 in August 1976 and March 1977.

\begin{tabular}{|c|c|c|c|c|}
\hline \multirow{2}{*}{ Species } & \multicolumn{2}{|c|}{ Aug. 1976} & \multicolumn{2}{|c|}{ Mar. 1977} \\
\hline & $400 \mathrm{~m}$ & $500 \mathrm{~m}$ & $400 \mathrm{~m}$ & $500 \mathrm{~m}$ \\
\hline \multicolumn{5}{|l|}{ Chlorophyta } \\
\hline Ulva japonica & & & 10.5 & 38.0 \\
\hline Codium fragile & & & 19.7 & \\
\hline \multicolumn{5}{|l|}{ Phaeophyta } \\
\hline Padina arborescens & & & 14.8 & \\
\hline Colpomenia sinuosa & & & 172.0 & 19.0 \\
\hline Ecklonia kurome & 38.6 & 6.9 & & \\
\hline Eckloniopsis radicosa & & & & 97.0 \\
\hline Undaria undarioides & & & 34.2 & 840.0 \\
\hline Sargassum piluliferum & & 15.6 & 72.2 & 67.7 \\
\hline \multicolumn{5}{|l|}{ Rhodophyta } \\
\hline Scinaia japonica & & & 163.9 & 37.5 \\
\hline Scinaia cottonii & & & 94.4 & 17.6 \\
\hline Galaxaura falcata & & & & 6.8 \\
\hline Galaxaura arborea & & 9.9 & & \\
\hline Gelidium amansii & & & 38.2 & 14.7 \\
\hline Gelidium pacificum & & & 14.5 & \\
\hline Pterocladia capillacea & 23.8 & & & \\
\hline Chondrococcus hornemannii & & & 9.3 & \\
\hline Halymenia acuminata & & & & 340.0 \\
\hline Carpopeltis divaricata & & & 118.5 & 43.1 \\
\hline Hypnea yamadai & & & 44.6 & 29.8 \\
\hline Gracilaria textorii & & & 360.0 & 156.6 \\
\hline Gracilaria bursa-pastoris & & & 192.5 & \\
\hline Gracilaria incurvata & & & 275.0 & 155.3 \\
\hline Gymbogongrus flabelliformis & & & 3.4 & \\
\hline Lomentaria catenata & & & 330.0 & 350.0 \\
\hline
\end{tabular}

